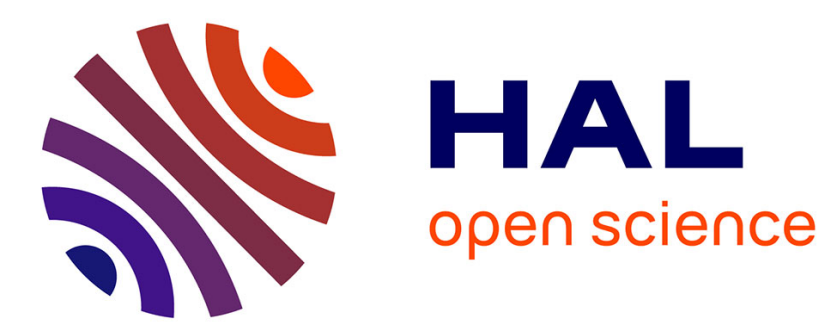

\title{
The British leave, but European Englishes remain
}

Marc Deneire

\section{To cite this version:}

Marc Deneire. The British leave, but European Englishes remain. World Englishes, 2017, 10.1111/weng.12267 . hal-02483441

\section{HAL Id: hal-02483441 https://hal.science/hal-02483441}

Submitted on 18 Feb 2020

HAL is a multi-disciplinary open access archive for the deposit and dissemination of scientific research documents, whether they are published or not. The documents may come from teaching and research institutions in France or abroad, or from public or private research centers.
L'archive ouverte pluridisciplinaire HAL, est destinée au dépôt et à la diffusion de documents scientifiques de niveau recherche, publiés ou non, émanant des établissements d'enseignement et de recherche français ou étrangers, des laboratoires publics ou privés. 


\title{
The British Leave, but European Englishes will Remain
}

\author{
Marc Deneire
}

\section{INTRODUCTION}

Brexit will no doubt be remembered as pivotal in European politics in the first part of this century. It has come as a surprise to most political and economic actors and observers; as a result, its impact is difficult to predict. As of today (February 2017), some of the effects are already being felt, especially in Britain. For example, universities are already worried about a 14 percent drop in international enrolments and job centers are experiencing a shortage of workers due to the return home of a sizeable number of Eastern European expatriates. However, it remains highly uncertain how Brexit will affect the European Union in general, and the development of English in that context. Any speculation will partly depend on the analysis of the present political situation. In that respect, my own analysis seems to be at the opposite ends of the spectrum to Marko Modiano's and, consequently, as are my conclusions concerning the spread of English in Europe.

\section{BREXIT AND EUROPE}

First, today's European Union is not a "global village" as Modiano seems to argue; rather it is dominated by all forms of divisions, by economic and political protectionism, not only in Britain of course, where the Northern Irish fear that the civil war might flare up again, but also everywhere in Europe where right and left-wing parties share varied forms of nationalism and populism marked by xenophobia and racism, and an adamant protection of culture and language at the national and regional levels (see e.g. the Front National in France, the Alternative für Deutschland in Germany, the Freiheitliche Partei Österreichs in Austria, the Movimento 5 Stelle in Italy, Geert Wilders' Partij voor de Vrijheid in the Netherlands, Viktor Orban's Fidesz in Hungary, and also the Flemish movement in Belgium and the movement of Catalan independence in Spain.

Second, Modiano falls in the traditional trap of comparing so-called "pro-English" and “anti-English" countries, somewhat predictably using Germany as an example of the first, and France to illustrate the latter. For that purpose, he uses quotations by German European Commissioner Gunther Ottinger on the one hand, and left-wing and right-wing French politicians Jean-Luc Mélanchon and Marine Le Pen on the other. Had he taken German nationalists and mainstream French politicians, he might have come out with a very different picture. For example, French finance minister Michel Sapin has been criticized for using 
English with French economic commissioner Pierre Moscovici; Foreign Policy presents presidential candidate Emmanuel Macron as "the English-speaking, German-loving French politician Europe has been waiting for" (http://foreignpolicy.com/2017/01/17/the-englishspeaking-german-loving-french-politician-europe-has-been-waiting-for-emmanuel-macron/), and most French politicians and business leaders have received the (in)famous "carpette anglaise" for "deserting the French language" and "promoting the domination of the AngloSaxon language" (http://www.langue-

francaise.org/Articles_Dossiers/Carpette_historique.php) On the other hand, Ulrich Ammon (2006) gives us a number of instances where German educational and cultural institutions actively resisted the spread of English in Germany. More recently, following the adoption of English as a company language by Volkswagen (17 years after Renault), Walter Krämer of the German language foundation deplored the fact that: "The words Volkswagen and the German language no longer go together" and added: "I am dismayed at how thoughtless our elites are giving up their own language and culture" (https://qz.com/875425/volkswagen-ischanging-its-official-language-from-german-to-english/).

In fact, 2011 Eurostat figures show that only $16 \%$ of the Germans claim to be fully proficient in English against $13 \%$ for the French. This may explain why when I spend my holidays in large German cities such as Köln or Munich outside university circles, I am often more successful communicating in a "germanized" version of one of my native languages, Dutch, rather than in English.

Finally, Modiano's paper may give the impression that most Europeans eagerly embrace globalization and "freely" adopt English as a result. This may be true for a small segment of the population, but not for the much larger part for whom globalization has meant lowering life conditions, and increased poverty, and unemployment. Brexit and other elections in Europe reflect the discontent and the frustration of the majority. Those who benefit from English proficiency are few, and even among them, many only reluctantly accept to use English when/because it is forced upon them (see e.g.,

https://www.youtube.com/watch?v=P8qIc_kLuek). As language economists have shown, proficiency in English may translate into a ten or twenty percent salary increase in certain jobs (Grin 2005), but for the $85 \%$ who are not proficient, it often means worsening life conditions, demotion, downgrading, or job loss.

Further, as Michael Hartman and Klarissa Lueg (2017) explain, Brexit is in part due to the decline in the homogeneity of European Elites. So far, Europeans Elites were usually drawn from the same national elite institutions, Oxbridge in Britain, The Ecole Nationale 
d'Administration (ENA) in France, etc., and dominate all spheres of society -economic, social, and cultural. However, globalization and internationalization have eroded the collusion between national elites and led to the creation of a new international Englishspeaking elite. As noted by A.-C Wagner (2011: 6):

The capital produced and legitimized by the State is now in competition with new sources of legitimacy that rely on a new form of international capital; this capital, which is inextricably cultural, linguistic, social, inherited to a large extent, and reinforced through international curricula and professional experience in several countries, appears to be particularly well-suited for the changing economic sphere.

This reminds us that English never comes alone, and in the present situation, it is clear that it primarily serves a form of class habitus that leads to the increasing isolation of a smaller and smaller elite. This may explain why Volkswagen, which became the number one auto-maker worldwide using German, now adopts English to attract international talent to high-level positions. The company clearly possesses plenty of industrial talent, but its development now depends on management by members of that small international elite.

In the 1930s and 1940s, the Marxist linguist Nikolaj Marr argued that economic revolutions produced linguistic revolutions and that all languages were class languages. For him, the speech of a French worker had more in common with that of a German worker than with that of a French capitalist. Paradoxically, his dream of a true international language may have become true, but it is that of a capitalist/financial class, not that of the proletariat.

\section{ON THE QUESTION OF EURO-ENGLISH}

Modiano is right to point out that English is making inroads into all walks of life in the European Union. However, for the following reasons, this does not make it "a variety in development": (1) it is mostly used in fairly closed communities of practice that are functionally and socially identifiable; in other words, English lacks both range and depth (Kachru 1986: 95) to qualify as a variety; (2) English has not been institutionalized in the way it has been in the Outer Circle. On the contrary, institutionalizing English in the European institutions for example would irremediably lead to the political breakup of the European Union (E. Roseau, Linguist at the European Council, personal communication); (3) it does not rely on an identifiable European culture and identity. The latest political and economic developments have shown over and over again that such a culture dos not exist. In fact, Modiano's range of features which, according to him, characterize the manner in which 
English is used in Europe are all formal features; they are not "culture-specific" in any way. Moreover, most of them are also used in non-native varieties of English. In my experience, the English used by Germans is "very German", that used by the Polish is "very Polish", etc., and indeed, the English used by people who have studied in the United States or Britain is "very international", but in no way European. All we may hope is that, following recent events and the present political reactions by the numerous casualties of globalization, this small international elite will come to an understanding that in a multilingual Europe, plurilingualism is the only option.

\section{REFERENCES}

Grin, François. 2005. L’enseignement des langues étrangères comme politique publique. Rapport établi à la demande du Haut Conseil de l'évaluation de l'école. Retrieved from: http://www.ladocumentationfrancaise.fr/var/storage/rapportspublics/054000678.pdf.

Hartmann, Michael \& Klarissa Lueg. 2017. Brexit: On the declining homogeneity of European elites - and on the importance of a domestic habitus in times of globalization. Culture, Practice and European Policy, 2/1, 28 - 34.

Kachru, Braj. 1990. The Alchemy of English. University of Illinois Press.

Morgan, Sam. 2017. VW ditches German as official language angers linguists. EurActiv January 4, 2017. Retrieved from http://www.euractiv.com/section/languagesculture/news/vw-ditches-german-as-official-language-angers-linguists/

Wagner, A.-C. 2011. Les classes dominantes à l'épreuve de la mondialisation. Actes de la Recherche en Sciences Sociales, 190, 5-35. 